\title{
Implementing Islamic Constitutionalism: How Islamic Is Indonesia Constitution?
}

\author{
Muhammad Siddiq Armia
}

\begin{abstract}
Implementing Islamic Constitutionalism: How Islamic Is Indonesia Constitution?. Religious constitutionalism has recently become a global discussion. Such a trend arises as a result of several countries that have a majority of religious adherents declare their constitution based on certain religions. Thailand, for example, provides special norms about Buddhism (Buddhist constitutionalism), the Vatican has special norms about Catholicism (Catholic constitutionalism), India has special norms about Hinduism (Hindu constitutionalism), Saudi Arabia has norms specifically about Islam (Islamic constitutionalism), and so on. This article analyzes whether or not the Islamic principles have been adopted in the Indonesian Constitution. These principles consist of protecting religion, soul, mind, offsprings, and property. The author uses the five principles as a standard in measuring the entire Indonesian Constitution which constitutes to the teachings of Islam (Islamic constitutionalism). The implementation of Islamic constitutionalism can be identified through articles in the constitution. This study concluded that, in general, the Indonesian constitution could be considered to have agreed to Islamic constitutionalism, although in some cases it still needs to be actualized more.
\end{abstract}

Keywords: Islamic constitutionalism, Indonesian's constitution, comparative constitutional

\begin{abstract}
Abstrak: Mengimplementasikan Konstitusionalisme Islam: Seberapa Islamkab Konstitusi Indonesia?. Konstitusionalisme agama baru-baru ini telah menjadi diskusi global. Kecenderungan seperti itu muncul dikarenakan beberapa negara yang memiliki mayoritas penganut agama, mendeklarasikan konstitusi mereka berdasarkan agama tertentu. Thailand, sebagai contoh, mengatur norma-norma khusus tentang agama Buddha (konstitusionalisme Buddha), Vatikan memiliki norma-norma khusus tentang Katolik (konstitusionalisme Katolik), India memiliki norma-norma khusus tentang Hindu (konstitusionalisme Hindu), Arab Saudi memiliki norma-norma khusus tentang Islam (konstitusionalisme Islam), dan sebagainya. Artikel ini menganalisis apakah prinsip-prinsip Islam telah diadopsi atau tidak dalam Konstitusi Indonesia. Prinsip-prinsip tersebut terdiri dari perlindungan terhadap agama, jiwa, akal pikiran, keturunan, dan harta benda. Penulis mengadopsi lima prinsip sebagai standar dalam mengukur sejauh Konstitusi Indonesia telah sejalan dengan ajaran Islam (konstitusionalisme Islam). Studi ini menyimpulkan bahwa, secara umum konstitusi Indonesia dapat dianggap telah mengadopsi konstitusionalisme Islam, meski dalam beberapa hal masih harus lebih diaktualisasikan.
\end{abstract}

Kata Kunci: konstitusi Islam, konstitusi Indonesia, konstitusional komparatif

Faculty of Sharia and Law, State Islamic University (UIN) Ar-Raniry Banda Aceh

J1. Syeikh Abdul Rauf Darussalam, Kopelma Darussalam, Syiah Kuala, Kota Banda Aceh

E-mail: msiddiq@ar-raniry.ac.id 


\section{Introduction}

Religious constitutionalism has recently become a global discussion. Such a trend arises as a result of several countries that have a majority of religious adherents declare their constitution based on certain religions. Thailand, for example, provides special norms about Buddhism, the Vatican has special norms about Catholicism, India has special norms about Hinduism, Saudi Arabia has norms specifically about Islam, and so on. ${ }^{1}$ Thus, countries having domination of religious norms can indicate as a country based on constitution taken from religious values, called Catholic constitutionalism, ${ }^{2}$ Hindu constitutionalism, ${ }^{3}$ Buddhism constitutionalism, ${ }^{4}$ and Islamic constitutionalism. ${ }^{5}$ As a part of religious constitutionalism, Islamic

${ }^{1}$ Javier García Oliva, Helen Hall, and Helen Hall, 'Human Rights and the Religious Character of the Constitution and the Wider Legal Framework', Religion, Law and the Constitution, 2017. <https://doi.org/10.4324/9781315734361-10>. Mahesh Srinivasan, Elizabeth Kaplan, and Audun Dahl, 'Reasoning About the Scope of Religious Norms: Evidence From Hindu and Muslim Children in India', Child Development, 0.0 <https://doi.org/10.1111/cdev.13102>. Ganefri Ganefri and others, 'Roles of the Kingdom of Saudi Arabia Toward the Development of Knowledge and Ulama', Khalifa Journal of Islamic Education, 1, no. 2 (2018), p. 135-47. Mohamed Abdelaal, 'Religious Constitutionalism in Egypt: A Case Study', Fletcher Forum of World Affairs, 37 (2013), p. 35. Jeffrie G. Murphy, 'Constitutionalism, Moral Skepticism, and Religious Belief', in Retribution Reconsidered: More Essays in the Philosophy of Law, ed. by Jeffrie G. Murphy, Philosophical Studies Series (Dordrecht: Springer Netherlands, 1992), p. 167-79 <https://doi.org/10.1007/978-94-015-7922-3_9>. Carol Weisbrod, 'Family, Church and State: An Essay on Constitutionalism and Religious Authority', Journal of Family Law, 26 (1987), p. 741.

2 Anna Su, 'Catholic Constitutionalism from the Americanist Controversy to Dignitatis Humanae', Notre Dame Law Review, 91 (2015), p. 1445.

${ }^{3}$ Brenda Cossman and Ratna Kapur, 'Secularism's Last Sigh: The Hindu Right, the Courts, and India's Stuggle for Democracy', Harvard International Law Journal, 38 (1997), p. 113.

${ }^{4}$ Roshan de Silva Wijeyeratne, Nation, Constitutionalism and Buddhism in Sri Lanka (N.p: Routledge, 2013) <https://doi.org/10.4324/9780203771631>. Benjamin Schonthal, 'Securing the Sasana through Law: Buddhist Constitutionalism and Buddhist-Interest Litigation in Sri Lanka', Modern Asian Studies, 50, no. 6 (2016), p. 1966-2008 <https://doi.org/10.1017/ S0026749X15000426>. Benjamin Schonthal, Buddhism, Politics and the Limits of Law: The Pyrrhic Constitutionalism of Sri Lanka (Cambridge University Press, 2016). Wijeyeratne, Andrew Harding, 'Buddhism, Human Rights and Constitutional Reform in Thailand', Asian Journal of Comparative Law, 2 (2007), p. 1-25 <https://doi.org/10.1017/S2194607800000016>. Iselin Frydenlund, 'Religious Liberty for Whom? The Buddhist Politics of Religious Freedom during Myanmar's Transition to Democracy', Nordic Journal of Human Rights, 35, no. 1 (2017), p. 55-73 <https://doi.org/10.1080/18918131.2017.1288950>.

5 Andrew Harding, 'Law, Religion, and Constitutionalism in Asia', Asian Journal of Comparative Law, undefined/ed, 1-6 <https://doi.org/10.1017/asjcl.2018.5>. Jaclyn L. Neo, 'Buddhism, Politics and the Limits of Law: The Pyrrhic Constitutionalism of Sri Lanka', International Journal of Constitutional Law, 16, no. 2 (2018), p. 720-23 <https://doi.org/10.1093/ icon/moy049>. Ran Hirschl and Ayelet Shachar, 'Competing Orders: The Challenge of Religion 
constitutionalism has also become a global discussion, especially in countries where its population adhere to a certain religion.

In fact, not all countries, including country dominantly Muslim, had established a specific religion within their constitution. Some countries even tend to hide their religious identity in their constitution although those countries have a majority in one religion. This can be found in most Western countries such as France, Canada, United States, Belgium, Sweden, Dutch, and so forth. ${ }^{6}$

Indonesia, having 222 million Muslims, has become the largest Muslim population in the world. In spite of the majority, there is no single norm in the Indonesian's constitution which arranges a specific position for the religion in the state. Indeed, the norms in Indonesian's constitution has a common meaning for all of the religions which are legally recognized in Indonesia. This situation often results in dissatisfaction among Muslim, particularly when they are facing with the demands to implement the Islamic teachings in some daily practices such as marriage, business, banking, philanthropy, and so forth. This is the reason why in Indonesia should have more Islamic regulation, although the country is, in fact, not a religious country.

This study is aimed at exploring the principle of Islamic constitutionalism by focusing on two main questions. Firstly, is there any country adopting Islamic constitutionalism? Secondly, how Islamic is Indonesian's constitution? These questions will be explored briefly in the explanation below.

\section{The Implementation of Islamic Constitutionalism in Indonesia Constitution}

\section{Islamic Constitutionalism in the Prophet Era}

Historically, Islamic constitutionalism was imposed in the time of Prophet Muhammad when he was in Medina. During that times, the Medina city was inhabited by multi tribes, faiths, and religions. To bind

to Modern Constitutionalism', University of Chicago Law Review, 85 (2018), p. 425.

${ }^{6}$ Timothy Tackett, Religion, Revolution, and Regional Culture in Eighteenth-Century France: The Ecclesiastical Oath of 1791 (Princeton University Press, 2014). Jean L. Cohen and Cécile Laborde, Religion, Secularism, and Constitutional Democracy (Columbia University Press, 2015). John Witte and Joel A. Nichols, Religion and the American Constitutional Experiment (Oxford University Press, 2016). 
the communities in a similar understanding and sense of belonging, Prophet Muhammad legislated the mutual agreement amongst the citizen of Medina city in $622 \mathrm{CE}$ (Common Era). The agreement later was recognized as the Medina Charter, has now been publicly claimed as a modern constitution.

The Medina Charter contained several things namely: (1) It acknowledged that the Prophet Muhammad as the leader of Muslims from the Quraysh tribe and from Yathrib. (2) It also declared to create the concept of one nation (called ummah wâhidah based on the nine existing tribes, namely the Qurayshi immigrants, followed by eight other tribes. Thus, it established the foundation of a multi-religious Islamic state-run in Medina. (3) The Charter also recognized Prophet Muhammad as the mediating consultant between groups and no fighting of war will occur without his approval. (4) The Charter had purposed to finish the nasty intertribal belligerent between the rival circles of Banu Aws and Banu Khazraj of Medinans and maintained peace and co-operation among all Medinan assemblies. In addition, (5) The Charter also asserted that councils of all parties, Muslim or non-Muslim, should involve in any wars and cooperation with external states. (6) This Chapter also has positioned Medina as the sacred place (called haram city), guaranteeing no blood of the peoples encompassed in the agreement can be dropped. The Madina Charter later has recognized publicly as the solid bedrock of Islamic constitutionalism. ${ }^{7}$

\section{Countries Adopting Islamic Constitutionalism}

There are many Muslim countries having implemented the Islamic principles in their constitution. Among them are the Kingdom of Saudi Arabia (KSA) and Brunei Darussalam. ${ }^{8}$ The KSA has a constitution that consists of nine chapters and 83 articles. The main sources of KSA's constitution are the Holy Qur'an, and the prophet Muhammad tradition

7 'Medina Charter and Just Peacemaking Theory | The Government - Annual Research Journal of Political Science.' <http://sujo.usindh.edu.pk/index.php/THE-GOVERNMENT/ article/view/1617>. Ridho al-Hamdi, 'Coping With Religious Tolerance and Gender Equality_ Comparing Islam and Good Governance Perspective', 2015 <http://repository.umy.ac.id/ handle/123456789/15584>.

${ }^{8}$ Frank E. Vogel, Islamic Law and the Legal System of Saudi: Studies of Saudi Arabia (Leiden: BRILL, 2000). 
(also called Hadits). KSA is one of the Muslim countries in the world that clearly asserts its identity as an Islamic state by referring to Al-Quran and Hadits as the grand norm of their constitution.

One of the serious matters in the KSA, however, is regarding the interpretation of their sources, the Holy Quran and the Hadits. Not all problems have been clearly regulated in the Holy Quran or Hadits. In addition, there are a number of verses of the Quran, and some Hadits as well, that need further interpretation before actualizing them with the recent context. Among the issues that often raise questions in the country are women rights, the concept of Mahram in the hajj, and so forth. Those matters have become problematic and clearly recognized as KSA's future work to accomplish.?

Second is Brunei Darussalam. Brunei declares itself as a Muslim country and puts the declaration in its constitution. To prevent conflicts in interpreting the Quran and the Sunnah, Brunei has imposed the Shâf; I school to be its official school as it is stated in Part II on Religion, stating that "The religion of Brunei Darussalam shall be the Muslim Religion according to the Shafeite sect of that religion." As a follow-up to this statement, Brunei Darussalam issued a number of legal rules based on Islamic Law, both covering civil and criminal matters. With regard to criminal law, although this rule has been approved since 2016 and will take effect in 2018, Sultan Haji Hassanal Bolkiah Mu'izzaddin Waddaulah, the Sultan of Brunei Darussalam, postponed the implementation of the rule due to the Criminal Sharia Courts The Procedure Code (CPC) prepared for that is still not accomplished. ${ }^{10}$

${ }^{9}$ Madawi Al-Rasheed, 'Modern Woman in the Kingdom of Saudi Arabia: Rights, Challenges, and Achievements', Journal of Middle East Women's Studies, 14, no. 3 (2018), p. 351-53 <https://doi.org/10.1215/15525864-7025483>. Fawziah Al-bakr and others, 'Empowered but Not Equal: Challenging the Traditional Gender Roles as Seen by University Students in Saudi Arabia', FIRE: Forum for International Research in Education, 4, no. 1 (2017) <https:// doi.org/10.18275/fire201704011083>.

${ }^{10}$ Dominik M. Müller, 'Sharia Law and the Politics of "Faith Control" in Brunei Darussalam. Dynamics of Socio-Legal Change in a Southeast Asian Sultanate', Internationales Asienforum, 46, no. 3-4 (2015), p. 313-45 <https://doi.org/10.11588/iaf.2015.46.3728>. 'Islamic Authority and the State in Brunei Darussalam', Kyoto Review of Southeast Asia <https://kyotoreview.org/issue-23/ islamic-authority-and-the-state-in-brunei-darussalam/>. 
What is still in question is whether the rule of law applies to all individuals in the country, including the royal family, or only to certain circles outside the palace family. This kind of question arises because in certain countries the law is often unable to reach the royal family. Their position in the royal family environment has made them immune from the law, both concerning general crimes and certain crimes such as corruption. The most striking example in this country is the case of Sultan Hassanal Bolkiah's nephew, Jefri, who was accused of embezzling billions of dollars from the Brunei Investment Agency into Amedeo Development in 2000. Nevertheless, after a private reconciliation with Sultan Bolkiah, the case was closed. ${ }^{11}$

\section{How Islamic is Indonesian's Constitution?}

\section{The Protection of Religious Affair}

As previously stated, the Indonesian constitution does not declare a particular religion as the philosophy of the state. In article 28 of the 1945 Indonesia Constitution, it is expressly stated that the state recognizes the existence of six religions in Indonesia - Islam, Christianity, Catholicism, Hinduism, Buddhism and Confucianism. Under such a statement, it is natural that the state then provides space for these religions to develop and practice its religious teachings as a whole. ${ }^{12}$

To respond this need, the government then issued a number of rules that contained religious values, including the law on the circulation of liquor/narcotics, the law on prostitution, gambling, and so on. In terms of protection of religion, article $28 \mathrm{E}$ of the 1945 Constitution states: "Every person is free to embrace religion and worship according to his religion, ...". This article gives freedom to all Indonesian citizens to

${ }^{11}$ J. Ng, 'Brunei Darussalam. Rule of Law for Human Rights', The ASEAN Region: A Base-Line Study, 2011, p. 33-51. Aurel Croissant and Philip Lorenz, 'Brunei Darussalam: Malay Islamic Monarchy and Rentier State', in Comparative Politics of Southeast Asia: An Introduction to Governments and Political Regimes, ed. by Aurel Croissant and Philip Lorenz (Cham: Springer International Publishing, 2018), p. 15-33 <https://doi.org/10.1007/978-3-319-68182-5_2>.

${ }^{12}$ Robert W. Hefner, 'Introduction: Indonesia at the Crossroads: Imbroglios of Religion, State, and Society in an Asian Muslim Nation', in Routledge Handbook of Contemporary Indonesia (N.p.: Routledge, 2018), p. 3-30. 
embrace and practice the teachings of the religion that they believe in. But this freedom is then limited by the provisions of article $28 \mathrm{~J}$ which states: "in practicing the rights and freedoms, each person is obliged to comply with the restrictions stipulated by law ...”.

This limitation is, to some extent, acceptable and is, indeed, needed to prevent the abuse of rights resulting in losses to other religious people. Because in practice there can be someone who practices religious teachings but unwittingly offends or harms other people, propagating any religion to other believesr, for. Instance. Such cases frequently occur in the community and have the potential to cause inter-religious conflict. So far conflicts with religious nuances have been resolved by issuing ministerial regulations, ${ }^{13}$ through political approaches rather than legal approaches; ${ }^{14}$ Completion of religious conflict through a political approach certainly does not solve the problem completely. Like treating a disease the policy only reduces the effect of the symptoms and does not reach the root of the real problem. Therefore, a legal regulation that regulates religious conflicts is absolutely necessary so that every religious conflicts can be resolved completely.

For Muslims, the government has issued several rules that can be used to regulate several civil law issues, which include: marriage law, Islamic banking and economic law, shari'ah insurance, and so on. The issuance of these rules signifies that although normatively Indonesia does not adhere to Islamic constitutionalism, in practice this country has adopted several basic principles from the Islamic teachings.

\section{The Protection of Soul and Life}

Article 28A of the 1945 Constitution states that "Everyone has the right to live and has the right to defend his life". This article clearly indicates that every individual living in Indonesia has similar rights to be

${ }^{13}$ Sofyan Hadi, 'Relasi dan Reposisi Agama dan Negara', Ri'ayah: Journal of Social and Religious, 3, no. 01 (2018), p. 12-30. Bisril Hadi, 'Problematika Pendirian Rumah Ibadah di Aceh (Analisis Peraturan Gubernur Aceh Nomor 25 Tahun 2007)' (unpublished B.S. thesis, UIN Syarif Hidayatullah Jakarta: Fakultas Ushuluddin, 2017).

${ }^{14}$ Robert W. Hefner, 'Religion, Law and Intolerance in Indonesia. Edited by Tim Lindsey and Helen Pausacker. (London: Routledge, 2016), p. 395. 
protected from any disturbance threatening his soul and life. Following up to this principle, the Indonesian government then drafted legal rules that would protect all residents from criminal acts. ${ }^{15}$ One problem related to the current national Criminal Law is that the law adheres to legal principles originating from foreign (Western) culture, not based on local traditions/culture. This occurs because the current National Criminal Law is nothing but a translation of Wetboek van Straftrecht, a colonial criminal law brought by the Dutch in the past colonial era. ${ }^{16}$

\section{Protection of Mind and Mental}

The issue of protection against mind and mentality health has not been expressly stated in the Indonesian constitution. Article $28 \mathrm{H}$ only regulates that Everyone has the right to live healthily physically and mentally, get a good and healthy environment and get health services. The rule of law regarding the health services mentioned in Article $28 \mathrm{H}$ does not only cover physical health problems but also mental health. This principle is then translated into a more concrete form of regulation, i.e the Law no. 36/2009 concerning health, which in paragraph 148 of the Act states that people having mental disorders have the same rights as normal citizens.

In addition to the laws governing the provision of mental health services, there are other laws that aim to protect citizens from the threat of mental damage resulting from the influence of drug abuse. Indeed drug problems have become a national problem for Indonesia, and the victims are not only limited to adults but also have spread to teenagers, even children. For this reason, the Government has issued a set of rules that will protect the public from drug abuse and at the same time provide severe legal sanctions for the dealers and the producers of the prohibited items. Unfortunately, the attention of the government is limited only to protecting the public from the dangers of drug abuse (narcotics) and has not touched the problem of

${ }^{15}$ Rudepel Petrus Leo, 'Trigger Factors of Nonlegitimized Discression Practices in the Criminal Law Enforcement by Police Department in Indonesia', JL Pol'y \& Globalization, 65 (2017), p. 114.

${ }^{16}$ Daniel S. Lev, 'Colonial Law and the Genesis of the Indonesian State', Law and Society in East Asia, 2017 <https://doi.org/10.4324/9781315091976-1>. William Hurst, Ruling Before the Law: The Politics of Legal Regimes in China and Indonesia (N.p.: Cambridge University Press, 2018). 
liquor, even though the potential mental/mental damage caused by liquor is almost similar to the danger posed by drug abuse. The only legal rule that pays attention to the problem of liquor is only the rule of law that applies in the Aceh region, reaching only limited to the internal province and does not apply nationally. This fact shows that although the Indonesian constitution has provided protection to its citizens from the threats of mind and mentality, the application of this principle is not optimal. More serious efforts are still needed to apply this principle of protection to real life. ${ }^{17}$

\section{Protection of Offsprings}

Article 28 B of Indonesian Constitution states: Everyone has the right to form a family and continues the descent through legal marriage. Such a declaration is in accordance with the fourth principle of Islam as identified by al-Shâtibi. The statement in article 28 B of the 1945 Constitution strengthens the regulations previously issued, namely Law No. 1/1974 concerning marriage. Similar to the application of the previous Islamic Constitution principles, the application of this principle is also inseparable from various shortcomings and weaknesses. The weaknesses/ shortcomings include various issues within the family law, ranging from interfaith marriages, restrictions on the minimum age of marriage, divorce, adoption. to the most recent issue, namely LGBT (Lesbian, Gay, Bisexual, and Transgender). ${ }^{18}$ The issues mentioned above, in reality, have not received serious attention from the government, even though these issues are very important and directly related to the principle of protection of offspring as mandated in article $28 \mathrm{~B}$.

${ }^{17}$ Bagas Heradhyaksa and Ruzian Markom, 'The Opportunities of the Application of Islamic Criminal Law According to Indonesian Constitution', Scientific Journal of PPI - UKM, 4, no. 1 (2017), p. 12-17-17.

${ }^{18}$ Hendri Yulius, Shawna Tang, and Baden Offord, 'The Globalization of LGBT Identity and Same-Sex Marriage as a Catalyst of Neo-Institutional Values: Singapore and Indonesia in Focus', in Global Perspectives on Same-Sex Marriage: A Neo-Institutional Approach, ed. by Bronwyn Winter, Maxime Forest, and Réjane Sénac, Global Queer Politics (Cham: Springer International Publishing, 2018), p. 171-96 <https://doi.org/10.1007/978-3-319-62764-9_9>. Zadrian Ardi, Frischa Meivilona Yendi, and Ifdil Ifdil, 'Students Attitude Towards LGBTQ: the Future Counselor Challenges', Jurnal Konseling dan Pendidikan, 5, no. 2 (2017), p. 74-79. 


\section{Protection of Property}

Protection of property has been stated in the Indonesian Constitution in article 33 clause 1 and 2. In the clauses, it is stated that (1) The economy is organized as a joint effort based on the principle of family. (2) Production branches that are important for the state and which control the livelihood of the public are controlled by the state." The protection of property principle has been followed up with the issuance of a series of government regulations that regulate economic problems. Among the regulations, the most relevant to the interests of the Muslim community are the Law on Sukuk, Waqaf, Islamic economics, and banking, etc As with the implementation of the previous four Islamic constitutional principles, the implementation of this principle in the form of government policy is not empty of criticism. Among a number of criticisms that emerged in this context were the problems of certain practices in the world of Islamic banking, which by some people were seen as having deviated from Islamic values and not even more than replication of conventional banking. ${ }^{19}$ Another issue that has also developed in the community is related to the idea of using dinars and dirhams besides the US dollar in business transactions. the proposal to use dinars and dirhams in daily economic transaction activities because these two currencies have a very low risk of inflation. ${ }^{20}$ Unfortunately, the proposal receives no approval from the Central Bank. ${ }^{21}$

\section{Conclusions}

Based on what has been previously presented, it can be concluded that from a number of countries that adopted Islamic Constitutionalism, Saudi Arabia is still experiencing problems in the interpretation of sources

${ }^{19}$ Mohamad Akram Laldin and Hafas Furqani, 'Innovation versus Replication: Some Notes on the Approaches in Defining Shariah Compliance in Islamic Finance', Al-Jamiah: Journal of Islamic Studies, 54, no.2 (2016), p. 249-272. Ahmad Khaliq and others, 'Interest Rate Risk Management and Islamic Banking: Evidence from Malaysia, Journal of Islamic Finance, 6, no. 1 (2017), p. 16-30.

${ }^{20}$ Khaulah Hilaluddin and Mohd M. Nazri, 'Dinar and Dirham: A Study On The Standard Measure Value of Goods and Services During The Prophet Muhammad's (Pbuh) Era', Global Journal al-Thaqafah, 8, no. 1 (2018), p. 83-91. Ahamed Kameel Mydin Meera, 'Islamic Gold Dinar: The Historical Standard', IJIEF: International Journal of Islamic Economics and Finance, 1, no. 1 (2018).

${ }^{21}$ Faisal M. Nasution and Gurpreet Dhillon, 'Shaping of Security Policy in an Indonesian Bank: Interpreting Institutionalization and Structuration', 2012. 
of Islamic law, the Qur'an and Al-Sunnah. This constraint in interpretation has made the country seemingly literal and conservative in understanding the aims and objectives of the two sources of Islamic law. While Brunei Darussalam, despite being free from the influences of conservatism and literalism, but the country tends to limit their interpretation only within the Shafi'ite school of law and rejects other schools for fear of causing a conflict of interpretation in the face of a legal problem.

As for Indonesia, even though this country does not explicitly declare of adhering to Islamic constitutionalism, but in practice, it adopts the principles that exist in Islamic constitutionalism and applies them in a number of legal rules. This can be seen in the rules giving protection to religious freedom, the soul, mind, descent, and property. Although it should be admitted that there are still a lot of works to be done in order to apply these principles more optimally.

\section{Bibliography}

Abdelaal, Mohamed. 'Religious Constitutionalism in Egypt: A Case Study', Fletcher Forum of World Affairs, 37 (2013), 35.

Al-Bakr, Fawziah, Elizabeth Bruce, Petrina Davidson, Edit Schlaffer, and Ulrich Kropiunigg. 'Empowered but Not Equal: Challenging the Traditional Gender Roles as Seen by University Students in Saudi Arabia', FIRE: Forum for International Research in Education, 4 (2017) $<$ https://doi.org/10.18275/fire201704011083>.

Al-Hamdi, Ridho, 'Coping With Religious Tolerance and Gender EqualityComparing Islam and Good Governance Perspective', $2015<\mathrm{http}: / /$ repository.umy.ac.id/handle/123456789/15584>.

Al-Rasheed, Madawi. 'Modern Woman in the Kingdom of Saudi Arabia: Rights, Challenges, and Achievements', Journal of Middle East Women's Studies, 14 (2018), 351-53 <https://doi.org/10.1215/15525864$7025483>$.

Ardi, Zadrian, Frischa Meivilona Yendi, and Ifdil Ifdil, 'Students Attitude Towards LGBTQ; the Future Counselor Challenges', Jurnal Konseling dan Pendidikan, 5 (2017), 74-79.

Cohen, Jean L., and Cécile Laborde, Religion, Secularism, and Constitutional Democracy. N.p.: Columbia University Press, 2015. 
Cossman, Brenda, and Ratna Kapur. 'Secularism's Last Sigh: The Hindu Right, the Courts, and India's Stuggle for Democracy', Harvard International Law Journal, 38 (1997), 113.

Croissant, Aurel, and Philip Lorenz. 'Brunei Darussalam: Malay Islamic Monarchy and Rentier State', in Comparative Politics of Southeast Asia: An Introduction to Governments and Political Regimes, ed. by Aurel Croissant and Philip Lorenz. Cham: Springer International Publishing, 2018.

Frydenlund, Iselin. 'Religious Liberty for Whom? The Buddhist Politics of Religious Freedom during Myanmar's Transition to Democracy', Nordic Journal of Human Rights, 35 (2017), 55-73 <https://doi.org/ 10.1080/18918131.2017.1288950>.

Ganefri, Ganefri, Fuady Anwar, Murniyetti Murniyetti, Zainurni Zein, and Sutria Rahayu. 'Roles of the Kingdom of Saudi Arabia Toward the Development of Knowledge and Ulama', Khalifa Journal of Islamic Education, 1 (2018), 135-47.

Hadi, Bisril. 'Problematika Pendirian Rumah Ibadah di Aceh (Analisis Peraturan Gubernur Aceh Nomor 25 Tahun 2007)' (unpublished B.S. thesis, UIN Syarif Hidayatullah Jakarta: Fakultas Ushuluddin, 2017) Hadi, Sofyan. 'Relasi dan Reposisi Agama dan Negara', Ri'ayah: Journal of Social and Religious, 3 (2018), 12-30.

Harding, Andrew. 'Buddhism, Human Rights and Constitutional Reform in Thailand', Asian Journal of Comparative Law, 2 (2007), 1-25 <https:// doi.org/10.1017/S2194607800000016.

- 'Law, Religion, and Constitutionalism in Asia', Asian Journal of Comparative Law, undefined/ed, 1-6 <https://doi.org/10.1017/ asjcl.2018.5>.

Hefner, Robert W. 'Introduction: Indonesia at the Crossroads: Imbroglios of Religion, State, and Society in an Asian Muslim Nation', in Routledge Handbook of Contemporary Indonesia. N.p.: Routledge, 2018.

. 'Religion, Law and Intolerance in Indonesia. Edited by Tim Lindsey and Helen Pausacker. London: Routledge, 2016.

Heradhyaksa, Bagas, and Ruzian Markom. 'The Opportunities of the Application of Islamic Criminal Law According to Indonesian Constitution', Scientific Journal of PPI - UKM, 4 (2017), 12-17. 
Hirschl, Ran, and Ayelet Shachar. 'Competing Orders: The Challenge of Religion to Modern Constitutionalism', University of Chicago Law Review, 85 (2018), 425.

Hurst, William. Ruling Before the Law: The Politics of Legal Regimes in China and Indonesia. (N.p.: Cambridge University Press, 2018.

'Islamic Authority and the State in Brunei Darussalam', Kyoto Review of Southeast Asia <https://kyotoreview.org/issue-23/islamic-authority-andthe-state-in-brunei-darussalam/>.

Khaliq, Ahmad, Hassanudin Mohd Thas Thacker, Anwar Allah Pitchay, and Mohd Asmy Mohd Thas Thacker. 'Interest Rate Risk Management and Islamic Banking: Evidence from Malaysia', Journal of Islamic Finance, 6 (2017), 016-030.

Laldin, Mohamad Akram, and Hafas Furqani. 'Innovation versus Replication: Some Notes on the Approaches in Defining Shariah Compliance in Islamic Finance', Al-Jamiah: Journal of Islamic Studies, 54 (2016), 249-272.

Leo, Rudepel Petrus. 'Trigger Factors of Nonlegitimized Discression Practices in the Criminal Law Enforcement by Police Department in Indonesia', JL Pol'y \& Globalization, 65 (2017), 114.

Lev, Daniel S. 'Colonial Law and the Genesis of the Indonesian State', Law and Society in East Asia, 2017 <https://doi.org/10.4324/9781315091976$1>$.

Meera, Ahamed Kameel Mydin. 'Islamic Gold Dinar: The Historical Standard', IJIEF: International Journal of Islamic Economics and Finance, 1 (2018).

Müller, Dominik M. 'Sharia Law and the Politics of "Faith Control" in Brunei Darussalam. Dynamics of Socio-Legal Change in a Southeast Asian Sultanate', Internationales Asienforum, 46 (2015), 313-45 <https://doi.org/10.11588/iaf.2015.46.3728>.

Murphy, Jeffrie G. 'Constitutionalism, Moral Skepticism, and Religious Belief', in Retribution Reconsidered: More Essays in the Philosophy of Law, ed. by Jeffrie G. Murphy, Philosophical Studies Series (Dordrecht: Springer Netherlands, 1992), pp. 167-79<https:/doi. org/10.1007/978-94-015-7922-3_9>.

Nasution, Faisal M., and Gurpreet Dhillon. 'Shaping of Security Policy in an 
Indonesian Bank: Interpreting Institutionalization and Structuration', 2012 .

Ng, J., 'Brunei Darussalam. Rule of Law for Human Rights', The ASEAN Region: A Base-Line Study, 2011, 33-51.

Oliva, Javier García, Helen Hall, and Helen Hall. 'Human Rights and the Religious Character of the Constitution and the Wider Legal Framework', Religion, Law and the Constitution, $2017<$ https://doi. org/10.4324/9781315734361-10>.

Schonthal, Benjamin. Buddhism, Politics and the Limits of Law: The Pyrrhic Constitutionalism of Sri Lanka. N.p.: Cambridge University Press, 2016.

. 'Securing the Sasana through Law: Buddhist Constitutionalism and Buddhist-Interest Litigation in Sri Lanka*', Modern Asian Studies, 50 (2016), 1966-2008 <https://doi.org/10.1017/S0026749X15000426>.

Srinivasan, Mahesh, Elizabeth Kaplan, and Audun Dahl. 'Reasoning About the Scope of Religious Norms: Evidence From Hindu and Muslim Children in India', Child Development, $0<$ https://doi.org/10.1111/ cdev.13102>.

$\mathrm{Su}$, Anna. 'Catholic Constitutionalism from the Americanist Controversy to Dignitatis Humanae', Notre Dame Law Review, 91 (2015), 1445.

Tackett, Timothy. Religion, Revolution, and Regional Culture in EighteenthCentury France: The Ecclesiastical Oath of 1791. N.p.: Princeton University Press, 2014.

Vogel, Frank E. Islamic Law and the Legal System of Saudi: Studies of Saudi Arabia. Leiden: BRILL, 2000.

Weisbrod, Carol. 'Family, Church and State: An Essay on Constitutionalism and Religious Authority', Journal of Family Law, 26 (1987), 741.

Wijeyeratne, Roshan de Silva. Nation, Constitutionalism and Buddhism in Sri Lanka N.p.: Routledge, 2013. <https://doi.org/10.4324/9780203771631>. Witte, John, and Joel A. Nichols, Religion and the American Constitutional Experiment N.p: Oxford University Press, 2016. 